\title{
TRANSAKSI JUAL BELI ON-LINE MELALUI MEDIA INSTAGRAM @PPSSHOP88 DENGAN AKAD SALAM
}

\author{
Ike Nuryanti Sulistyowati \\ Arfan Muammar \\ e-mail: ikenuryanti24@gmail.com
}

\begin{abstract}
ABSTRAK
Dalam transaksi muamalah yang modern ini muncul perkembangan teknologi yang baru, jual beli online bisa dilakukan melalui media instagram @ppshop88. Karena pengaruh teknologi tersebut maka dianggap penting untuk mengkaji lebih lanjut terkait praktik jual beli on line tersebut berikut keabsahan akadnya. Ini merupakan penelitian hukum deskriptif, pengumpulan data dilakukan dengan cara mengkaji pustaka tentang jual beli online kemudian dianalisis dengan cara pemeriksaan data, klasifikasi data dan analisis data. Hasil penelitiannya menggambarkan: 1) praktik jual beli online melalui media instagram @ppsshop dilakukan pada awalnya membuka profil instagram, dilanjutkan dengan melihat produk-produk yang ditawarkan 2) Jual beli online adalah mubah (boleh), rukun dan syarat jual beli online tidak bertentangan dengan rukun dan syarat dalam sistem hukum perikatan Islam. 3) Transaksi jual beli online akad salam sesuai dengan Fatwa DSN MUI No 05/DSN-MUI/IV/2000 tentang Jual Beli Salam, dikarenakan dalam akad tersebut tidak menyalahi aturan syariat yang ada, sehingga kedepannya adanya Fatwa tersebut harus diakui keberadaannya dan diimplementasikan dalam kegiatan ekonomi yang dimaksud.
\end{abstract}

Kata kunci: Jual Beli On Line, Media Instagram, Akad Salam

\section{PENDAHULUAN}

Sejarah telah meriwayatkan, bahwa hidup Rosulullah Saw tidak lepas dari kegiatan bisnis. Sikap Rosulullah Saw dalam menjalankan bisnis sangat mengedepankan nilai moral yang bertujuan untuk memuaskan pembeli. Dalam arti ilmiyah, bisnis adalah suatu kegiatan usaha yang sifatnya untuk mencari keuntungan. Oleh karenanya Konsep yang dijalankan dalam berbisnis disebut value driven yang mempunyai arti menjaga, mempertahankan, menarik nilai-nilai dari pelanggan. Value Driven juga erat hubungannya dengan relationship marketing yaitu berusaha menjalin hubungan erat antara pedagang, produsen dengan pelanggan. ${ }^{1}$

Berkaitan dengan bisnis, Allah telah mengaturnya sebagaimana yang telah tercantum dalam Firmannya Surat An-Nisa: 29, sebagai berikut; "Hai orang-orang yang beriman, janganlah kamu saling memakan harta sesamamu dengan jalan yang batil, kecuali dengan jalan perniagaan yang berlaku dengan suka sama-suka di antara kamu. dan janganlah kamu membunuh dirimu; Sesungguhnya Allah adalah Maha Penyayang kepadamu.",2

\footnotetext{
1 Buchari Alma, Dasar-Dasar Etika Bisnis Islam (Bandung: Alfabeta, 2003), 21

${ }^{2}$ Al-Qurān An-Nisa: 29
} 
Islam tidak membatasi kegiatan jual-beli hanya untuk memenuhi kebutuhan pribadi saja, melainkan juga untuk mendapatkan keuntungan yang berkah agar nantinya hasil dari keuntungan tersebut dapat dipergunakan dijalan Allah. Dengan demikian, jual beli dalam islam pada hakekatnya tidak hanya bersifat konsumtif dan hanya mengandung unsur material untuk memperoleh keuntungan di dunia, tetapi juga keutungan hakiki di akhirat dengan memperhatikan prinsip-prinsip jual beli yang berbasis syariah.

Dalam transaksi muamalah yang modern ini muncul perkembangan teknologi yang baru, salah satunya adalah jual beli sistem online atau elektronik commerce (E-Commerce) yang mana teknologi ini telah menciptakan jenis-jenis dan peluangpeluang bisnis baru yang dilakukan melalui alat elektronika ini. Melalui alat elektronik, banyak kemudahan bagi manusia dalam berbagai bidang, salah satunya adalah bidang perniagaan atau jual beli. Jual beli jaman modern ini dapat dilakukan dengan alat teknologi atau dengan cara sistem online yang dikembangkan oleh jaringan internet untuk memberikan kemudahan bagi manusia. $^{3}$

Teknologi merupakan sebuah perangkat untuk membantu aktivitas manusia dan dapat mengurangi ketidakpastian yang disebabkan oleh hubungan sebab akibat yang melingkupi dalam mencapai sebuah tujuan. ${ }^{4}$ Teknologi menghubungkan manusia dengan kemudahan dalam mencari berbagai hal yang tidak diketahui sebelumnya, melalui majunya perkembangan teknologikomunikasi, sebuah media penghubung yang

\footnotetext{
${ }^{3}$ Supriyadi, Hukum Bisnis (Bandung: PT

Rineka, 2008), 28

4 Agoeng Noegroho, Teknologi Komunikasi (Yogyakarta: Graha Ilmu, 2010), 2
}

dinamakan internet mulai menyebar luas sebagai salah satu media komunikasi dan informasi.

Keberadaan jual beli online merupakan alternative bisnis yang cukup menjanjikan untuk diterapkan pada saat ini, karena jual beli onlinememberikan banyak kemudahan bagikedua belah pihak, baik dari pihak penjual (merchant) maupun dari pihak pembeli (buyer) di dalam melakukan transaksi perdagangan, meskipun para pihak berada di dua tempat berbeda sekalipun. Dengan jual beli onlinesetiap transaksi tidak memerlukan pertemuan dalam tahap negosiasi. Oleh karena itu jaringan internet ini dapat menembus batas geografis dan teritorial termasuk yurisdiksihukumnya. ${ }^{5}$

Penggunaan internet sebagai media perdagangan terus meningkat dari tahun ke tahun. Hal ini disebabkan oleh berbagai manfaat yang didapat oleh perusahaan ataupun konsumen dengan melakukan transaksi melalui internet. Manfaat dari digunakannya jual beli online ini adalah dapat menekan biaya barang dan jasa, serta dapat meningkatkan kepuasan konsumen sepanjang yang menyangkut kecepatan untuk mendapatkan barang yang dibutuhkan dengan kualitas yang terbaik sesuai dengan harganya.

Kegiatan jual beli online, kebanyakan para pelakunya adalah kaula muda, seperti yang dikutif dari okezone.com. belakangan ini bisnis online kian menjamur ditanah air. Hal ini tak lepas dari jumlah pengguna internet yang terus meningkat. Dikatakan juga bahwa pelaku bisnis online banyak dari kalangan mahasiswa dan ibu rumah tangga yang ingin turut

\footnotetext{
${ }^{5}$ www.articles of business system.com, diakses tanggal 02 Agustus 2017
} 
mensejahterakan kehidupan rumah tangganya. ${ }^{6}$

Salah satu media sosial yang dapat digunakan untuk kegiatan jual beli online yaituinstagram. Instagram yaitu sebagai media sosial untuk membuat foto dan mengirimkannya dalam waktu yang sangat cepat. Tujuan tersebut sangat dimungkinkan oleh teknologi internet yang menjadi basis aktivitas dari media sosial ini. Transaksi jual beli melalui mediainstagram ini menjadi alternatif yang menarik dan sangat diminati bagi pembeli pada saat ini khususnya perempuan. Hal ini didukung oleh hasil penelitian yang menyatakan bahwa pembeli tertarik melakukan transaksi melalui media instagram ini karena mudah mencari barang yang diinginkan, dapat membandingkan harga, kemudian pembayaran yang dilakukan cukup mudah hanya dengan transfer, dan hanya menunggu barang datang tanpa harus keluar rumah, sehingga mengekfektifkan mengefisiensikan waktu karena transaksi dapat dilakukan oleh setiap orangkapan saja dan dimana saja. $^{7}$

Transaksi jual beli melalui Instagram, hampir sama dengan perjanjian jual beli pada umumnya, ${ }^{8}$ perjanjian jual beli melalui instagramini pun berawal dari penawaran dan penerimaan. Penawaran yaitu suatu perbuatan seseorang beralasan bahwa perbuatan itu sendiri sebagai ajakan untuk masuk ke dalam suatu ikatan

\footnotetext{
${ }^{6}$ www. Okezone. com. Diakses pada tanggal 02 Agustus 2017

${ }^{7}$ http://www.selipan.com/story/style/7-alasankenapa-penduduk-instagramkebanyakancewek/, diakses pada 27 Februari 2018

8 Menurut KUHPerdata Pasal 1457 jual beli adalah "suatu perjanjian, dengan mana pihak yang satu mengikatkan dirinya untuk menyerahkan suatu kebendaan, dan pihak yang lain untuk membayar harga yang telah dijanjikan".
}

perjanjian. ${ }^{9}$ Penawaran pada transaksi jual beli melalui instagram ini yang melakukan adalah pihak penjual, yang mana penjual memanfaatkan instagram ini untuk menampilkan produk dagangan yang ditunjukan pada halaman timelineinstagram calon pembelinya, dan diikuti dengan penerimaan oleh pihak pembeli.

Penjualan di instagram ini menggunakan sistem penawaran dan interaksi yang mudah dilakukan sehingga memunculkan banyak peminat yang tertarik untuk melakukan transaksi melalui mediainstagram ini. Ramainya pengguna instagram menjadi salah satu alasan kuat mengapa orang-orang menyukai media sosial tersebut sebagai tempat berjualan online.

Penggunaan internet dalam jual beli on-line ini memberikan dampak yang sangat positif, yakni dalam kecepatan dan kemudahan serta kecanggihan dalam melakukan interaksi global tanpa batasan tempat dan waktu yang kini menjadi hal yang biasa. Transaksi bisnis yang lebih praktis tanpa perlu kertas dan pena, perjanjian face to face(bertemu secara langsung) pelaku bisnis ini tidak diperlukan lagi, sehingga dapat dikatakan perdagangan elektronik atau ini menjadi penggerak ekonomi baru dalam bidang teknologi khususnya di indonesia. ${ }^{10}$

Berdasarkan kelebihan di atas, tidak dapat dipungkiri pula adanya risiko yang mungkin timbul dalam transaksi ini karena dilakukan tanpa ada pertemuan antara para pihaknya. Mereka mendasarkan transaksi jual beli ini atas rasa kepercayaan satu sama lain

\footnotetext{
9 Mariam Darus Badrulzaman, E-Commerce Tinjauan Dari Hukum Kontrak Indonesia, (Jakarta: Citra Aditya Bakti, 2001), 33

10 Abdul Halim Barakatullah dan Teguh Prasetyo, Bisnis E-Commerce Studi Sistem Keamanan dan Hukum di Indonesia (Jakarta: Pustaka 2008), 3
} 
karena bagaimanapun transaksi jual beli tidak lepas dari masalah perjanjian. ${ }^{11}$ Oleh karena itu, perjanjian jual beli yang terjadi diantara para pihak pun dilakukan secara elektronik juga, dan tidak ada berkas perjanjian seperti pada transaksi jual beli pada umumnya. Kondisi seperti ini tentu dapat menimbulkan berbagai akibat hukum dengan segala risikonya, antara lain apabila muncul suatu perbuatan wanprestasi dari salah satu pihak dalam transaksi tersebut, kemudian bagaimana pertanggungjawaban salah satu pihak apabila melakukan wanprestasi dan masalah lain seperti tidak ada kewajiban dari pihak penjual untuk melakukan konfirmasi kepada pembeli. ${ }^{12}$

Berdasarkan permasalahan di atas tentu hal ini sangat merugikan salah satu pihak. Berdasarkan permasalahan tersebut tentu akan menyulitkan pihak yang dirugikan untuk menuntut segala kerugian yang timbul yang disebabkan oleh perbuatan tersebut. Namun, untuk mencegah beberapa masalah seperti di atas, pemerintah turut berperan sebagai sarana untuk memecahkan berbagai problem sosial yangcukup tegas sehingga dapat memberikan sanksi bagi yang menyalahgunakan transaksi elektronik ini, dan peraturan ini merupakan wujud dari tanggung jawab negara untuk memberikan perlindungan maksimal pada seluruh aktivitas pemanfaatan teknologi informasi dan komunikasi di dalam negeri agar terlindungi dengan baik dari potensi penyalahgunaan teknologi. ${ }^{13}$

Selanjutnya, dalam penelitian ini berusaha mengimplementasikan bentuk

\footnotetext{
${ }^{11}$ Sril Sitompul, Hukum Internet, (Bandung: Citra Aditya Bakti, 2004), 55.

${ }^{12}$ Setiawan, Electronic Commerce: Tinjauan

Dari Segi Hukum Kontrak, (Jakarta: Rineka

Cipta, 2000), 4.

${ }^{13}$ Neni Sri Imaniyati, Hukum Bisnis,

(Yogjakarta: Graha Ilmu, 2013), 255.
}

jual beli online melalui media Instagram@PPSHOP88 yang mana awalnya yang mengikuti postingan @ppshop88, selaku konsumen memilih produk/memesan produk sesuai yang di postkan, kemudian mempelajari karakteristik produk, setelah disepakati terjadilah pemesanan yang kemudian konsumen melakukan pembayaran. Selanjutnya menunggu kiriman barang yang dipesan sebelumnya tersebut. Adapun model transaksi jual beli on line seperti ini adalah dikenal dengan akad salam.

Adanya transaksi jual beli online ini butuh dikaji secara mendalam lagi karena dari berbagai penelitian belum ada yang secara spesifikasi membahas tentang jual beli online melalui media instagram sebagaimana karya peneliti ini. Adapun karya terdahulu yang dapat dijadikan sebagai bahan rujukan dan juga sebagai bahan pembanding perbedaan antara penelitian terdahulu dengan penelitian ini, diantaranya.

Tinjauan Hukum Islam tentang Jual Beli Via Telepon dan Internet oleh Sofyan. Dalam artikel ini membahas mengenai bagaimana pandangan hukum Islam tentang jual beli melalui telepon dan internet, sehingga sangat pentingbagi penulis untuk menjadikannya sebagai referensi dalam pembahasan tesis ini.

Karya Ana Faiqoh Jurusan Muamalah tahun 2011 membahas tentang masalah perkembangan internet, yang berjudul "Penjiblakan Karya Tulis di Internet Dalam Pandangan Hukum Islam".

Dalam karya ini memberi kesimpulan bahwa, penjiblakan karya tulis di internet menurut UUHC No. 12 tahun 1997 termasuk kategori pelanggaran hak cipta dan pelakunya dapat dikenai sanksi perdata, berupa pemenuhan ganti rugi sejumlah yang ditentukan oleh penggugat dan 
penyitaan perbanyakan benda bergerak hasil pelanggaran hak cipta. Disamping itu, penjiplakan karya tulis di internet termasuk tindak pidana biasa. ${ }^{14}$

Sayid Hamid tahun 2011 dengan judul “ Penggunaan Merek Orang Lain Sebagai Domain Name Internet Dalam Perspektif Undang-Undang Merek dan Hukum Islam". ${ }^{15}$

Hasil penelitian penyimpulkan bahwa menurut UU merek No.19 tahun 1992, yang dimaksud merek adalah tanda berupa gambar, tulisan, nama atau kata-kata, huruf-huruf, angka-angka, susunan warna atau kombinasi unsurunsur tersebut yang memiliki daya pembeda untuk digunakan sebagai kegiatan perdagangan barang atau jasa. Sedangkan nama domain yang berupa nama, susunan huruf, kata atau angka yang seringkali digunakan dapat dikategorikan merek karena ia juga memiliki daya pembeda.

Dari data uraian tinjauan pustaka di atas dapat diambil kesimpulan bahwa: pertama, membahas jual beli lewat televon dan internet, kedua hak kepemilikan domain name yang ada di internet sebagaikepemilikan bagi yang membuat tersebut. Kemudian yangketigamenjelaskan, bahwa penjiblakan karya tulis di internet, merupakan pelanggaran hak cipta dan pelakunya dapat dikenai sanksi perdata.

Dari sini jelas bahwa penelitian yang dibahas oleh ketiga penulis di atas sangat berbeda. Adapun penelitian/pembahasan dalamtesis ini yang berjudul "Transaksi Jual Beli OnLine Melalui Media Instagram @Ppsshop88 Dengan Akad Salam”.

\footnotetext{
${ }^{14}$ Ana Faiqoh Jurusan. 2011. Penjiblakan Karya Tulis di Internet Dalam Pandangan Hukum Islam.

15 Sayid Hamid. 2011. Penggunaan Merek Orang Lain Sebagai Domain Name Internet Dalam Perspektif Undang-Undang Merek dan Hukum Islam
}

Penulis lebih memfokuskan pada bagaimana praktek transaksi pada media Instagram @ppshop88, kemudian dilanjutkan untuk menilai kesesuaian praktek transaksi tersebut dengan Fatwa DSN MUI tentang Jual Beli Salam. Oleh karenanya dalam tesis ini berbeda dengan kajian terdahulu sebagaimana yang telah dipaparkan di atas.

Dalam penulisan artikel ini mempunyai tujuan, yaitu Mendeskripsikan praktikdan keabsahan transaksi jual beli on-line melalui media Instagram @ppsshop88 dengan akad salam. Mendeskripsikan kesesuaian praktik jual beli online media Instagram @ ppsshop88akad salam dengan prinsipprinsip Fatwa DSN MUI No 05/DSNMUI/IV/2000 tentang jual beli salam.

\section{PEMBAHASAN}

\section{Praktek dan Keabsahan Transaksi Jual Beli On Line Melalui Media Instagram @Ppsshop88 Dengan Akad Salam}

Sudah dikatakan sebelumnya, bahwa transaksi jual beli on line harus bermodalkan jaringan internet. Kemudian mengunjungi tempat-tempat jual beli on line. Misalnya, Marketplace (Bukalapak.com dan Tokopedia.com), Website (OLX.com, Web blog (www.bajumuslimtermurah.blogspot.co m, http://morinabusana.blogspot.com), Forum (Kaskus.co.id, Paseban.com), Media Sosial (Facebook, twitter, instagram, WA, BBM dan lain-lain).

Setelah konsumen mengunjungi dan memilih tampat jual beli on line tersebut, kemudian konsumen melihat dan memilih produk yang dipasarkan sesuai dengan keinginanya berdasarkan kriteria-kriteria tertentu dan spesifikasinya, untuk kemudian mempelajari term of condition untuk melakukan kontrak kesepakatan. Misalnya terkait sistem pembayaran, estimasi pengiriman dan lain lain. Jika 
konsumen tidak sepakat dengan perjanjian tersebut maka bisa langsung dibatalkan namun jika sudah sepakat maka kedua belah pihak harus menjalankan kesepakatan masingmasing.

Dalam transaksi jual beli online ini hanya bermodalkan saling percaya diantara pelaku usaha dan konsumen. Perjanjian mereka terbentuk setelah adanya kesepakatan yaitu konsumen mengirimkan sejumlah uang seharga barang (transfer) dan kemudian pelaku usaha untuk bersiap mengirimkan ke alamat tujuan konsumen. Dalam menggunakan sistem teknologi ini semua pihak harus menggunakan dengan bijaksana agar tidak timbul sikap yang saling menipu sehingga terjadi wan prestasi diantara salah satu pihak.

Selanjutnya bahwa walaupun kita tidak membuka sebagaimana situssitus di atas, ternyata produk online itu juga bisa didapatkan melalui media sosial yang lain misalnya Facebook, BBM, WA bahkan juga Instagram. Dalam Facebook ketika kita membukanya terasa berada dalam sebuah mall karena beranda dipenuhi dengan penawaran produk berdasarkan spesifikasi-spesifikasi yang unggul dan lain-lain, dalam BBM biasanya dipasarkan dalam sebuah grup begitu juga dalam WA. Tak ketinggalan juga dalam Instagram yang menawarkan berbagai keunggulan sebuah produk.

Instagram merupakan sebuah aplikasi berbagi foto dan video yang memungkinkan pengguna mengambil foto dan membagikannya ke berbagai layanan jejaring sosial termasuk di dalam instagram sendiri. Berdasarkan pengertian tersebut maka sangat bermanfaat sekali jika media instagram digunakan sebagai alat untuk memasarkan produk yang dikemas sedemikian rupa sehingga dapat menarik konsumen-konsumen untuk memesan barang sebagaimana yang dipasarkannya.

Sebagaimana dalam pembahasan ini yaitu jual beli yang dilakukan melalui media Instagram @Ppsshop88. Langkah pertama yang harus dilakukan konsumen untuk melihat penawaran produk Olshop tersebut, diantaranya:

a. Konsumen memiliki media Instagram, yaitu konsumen mendaftarkan terlebih akun instagramnya yang dapat dilakukan pendaftaran dengan menggunakan akun Facebook atau Nomer HP pengguna.

b. Konsumen mengikuti atau meng-add Ppsshop88 untuk menjadi pertemanan atau mengikuti postingan ppsshop88.

c. Setelah konsumen mengikuti postingan tersebut maka secara otomatis, produk apa yang dipasarkan oleh ppsshop konsumen bisa melihatnya, selain itu dalam produknya juga dilengkapi dengan spesifikasi barang, mulai dari harga, ukuran, jenis kain, model produk, maupun pembuatan produk.

d. Setelah konsumen menyatakan cocok terhadap suatu barang tertentu kemudian keduanya (penjual dan pembeli) mengadakan kontrak jual beli dan seterusnya yang nentinya juga mengarah pada sistem pembayaran dan peneriman barnag tersebut.

Berdasarkan mekanisme tersebut di atas, kemudian kedua belah pihak mempunyai tanggung jawab masingmasing yang harus dijalankan yaitu pembeli segera melakukan pembayaran dan penjual segera mempacking barang dan kemudian dikirimkan kealamat pembeli. Dalam transaksi ini dikenal dengan istilah jual beli salam.

Kegiatan jual beli media instagram. Dilihat dari sisi ekonomi 
islam, pada dasarnya segala bentuk kegiatan muamalah adalah diperbolehkan kecuali terdapat aturan syara' yang melarangnya. Begitu juga untuk mengetahui status keabsahan jualbeli on line dengan akad as-salam, bertentangan dengan syari'ah ataupun tidak, maka perlu menetapkan metode istinbath hukum yang dipakai. Dalam jual beli ini (jual beli on line akad assalam) harus disinergikan dengan syarat dan rukun jual beli pada umumnya. Diantaranya:

\section{Orang yang Berakad}

Secara umum al-'aqid (pelaku) jual beli disyaratkan harus ahli dan memiliki kemampuan untuk melakukan akad atau mampu menjadi pengganti orang lain jika ia menjadi wakil.

Ditegaskan pula sebagaimana kajian terdahulu sebelumnya bahwa syarat orang yang berakad (almuta'aqidain) yang terdiri dari penjual dan pembeli, haruslah orang yang telah cakap dalam bertindak terhadap harta dan berbuat kebajikan, transaksi jual beli ini haruslah dilakukan oleh orang yang telah sempurna akalnya (al-'aql), sudah mencapai usia yang telah mampu untuk membedakan yang baik yang buruk (al-mumayyiz). ${ }^{16}$

Dalam transaksi jual beli online akad as-salam, dapat dipastikan masingmasing pihak yang terlibat transaksi telah memenuhi kriteria tamyiz dan telah mampu mengoperasikan komputer dan tentunya telah memenuhi ketentuan memiliki kecakapan yang sempurna atau akal yang sehat serta mempunyai wewenang untuk melakukan transaksi. Selanjutnya dalam transaksi ini tidak mungkin dilakukan oleh orang yang tidak memiliki kecakapan yang sempurna, sepertidilakukan oleh anak kecil yang belum berakal atau orang gila.

16 Amir Syarifuddin, Garis-Garis Besar Fiqh, (Jakarta: Prenada Grup, 2007), 196
Adapun keberadaan penjual dan pembeli, meskipun dalam transaksi jual belionline tidak bertemu langsung, akan tetapi melalui internet telah terjadi saling tawar-menawar atau interaksi jual beli antara penjual dan pembeli. Dengan demikian syaratorang yang berakad dalam jual beli on line ini telah terpenuhi.

2. Sighat (Lafal Ijab dan Kabul)

Sighat akad (ijab dan kabul)

adalah sesuatu yang disandarkan dari dua pihak yang berakad yang menunjukkan atas apa yang ada dihati keduanya tentang terjadinya suatu akad. Wahbah al-Zuhaili memberi definisi akad dengan makna pertemuan ijab dan kabul yang dibenarkan oleh syara' yang menimbulkan akibat hukum terhadap objeknya. ${ }^{17}$

Dalam hukum Islam, pernyataan ijab dan kabul dapat dilakukan dengan lisan, tulisan atau surat-menyurat, atau isyarat yang memberi pengertian dengan jelas tentang adanya ijab dan kabul dan dapat juga berupa perbuatan yang telah menjadikebiasaan dalam ijab dan kabul.

Secara khusus syarat-syarat ijab qabul yang harus dipenuhi dalam jual beli salam adalah:

a) Tujuan yang terkandung di dalam pernyataan ijab dan qabul harus jelas dan terdapat kesesuaian, sehingga dapat dipahami oleh masing-masing pihak.

b) Pelaksanaan ijab dan qabul harus berhubungan langsung dalam suatu majlis. Apabila kedua belah pihak hadir dan

\footnotetext{
17 Wahbah al-Zuhaili, Al -Fiqh al -Islami wa Adillatuhu , Jilid IV (Beirut: Dar al-Fikr, 1989), 81
} 
saling bertemu dalam

satu tempat untuk

melaksanakan

transaksi, maka

tempat tersebut adalah majlis akad.

Adapun jika masing-

masing pihak saling

berjauhan maka

majlis akad adalah

tempat terjadinya

qabul $^{18}$.

Tujuan yang terkandung dalam pernyataan ijab dan kabul harus jelas dan dapat dipahami oleh masing-masing kedua belah pihak yang melakukan transaksi jual beli. Selain itu, pelaksanaan ijab dan kabul juga harus berhubungan langsung dalam suatu majelis. Adapun ijab dan kabul dibolehkan ditempat yang berbeda selama antara penjual dan pembeli sudah memahami satu sama lain.

Pengertian satu majelis tidak sekedar pertemuan dalam satu ruangan secarafisik antara penjual dan pembeli, oleh karenanya transaksi jual beli lewat sarana jarak jauh apa saja dapat dikategorikan sebagai satu majelis. Termasuk juga via telepon,internet, atau media cetak dan elektronik lainnya, asalkan masih dalam konteks yan sama, yaitu akad jual beli. ${ }^{19}$

Selanjutnya mengenai satu majelis ini, Wahbah al-Zuhaili menyatakan bahwa maksud satu majelis bukanlah bermakna kedua belah pihak yang melakukan akad itu harus beradaditempat yang sama. Sebab boleh jadi seseorang duduk ditempat yang lain dan seorang lagi berada ditempat lain. Tetapi keduanya dapat melakukan kontak hubungan bisnis. Dengan demikian, yang dimaksud dengan satu majelis adalahketika terjadi transaksi,

\footnotetext{
${ }_{18}^{18}$ Rahmat Syafi'i, Fiqih Muamalah, 51.

19 Sofyan AP. Kau, Tinjauan Hukum Islam

Tentang Jual Beli Via Telepon dan Internet, 10
}

kedua belah pihak (penjual dan pembeli) berada dalam satu masa atauwaktu. $^{20}$

Dalam prakteknya, transaksi jual beli online as-salam, penjual dan pembeli bertemu dalam satumajelis, yaitu yang dinamakan majelis maya. Penjual dan pembeli tidak berada dalam satu tempat tertentu namun berada dalam akad yang sama yaitu pemilik usaha menjual produknya lewat media dan pembeli melihat produknya juga melalui media.

3. Objek Transaksi Jual Beli

Objek transaksi jual beli harus ada atau tampak pada saat akad terjadi. Terhadap objek yang tidak tampak, ulama Syafi'iyah dan Hanafiyah melarang secara mutlak, kecuali dalam beberapa hal seperti jasa. Namun demikian, ulama fikih sepakat bahwa barang yang dijadikan akad harus sesuai dengan ketentuan syara',seperti objek yang halal, dapat diberikan pada waktu akad, diketahui oleh kedua belahpihak, dan harus suci. ${ }^{21}$

Bentuk objek akad dapat berupa benda berwujud dan benda yang tidak berwujud. Mengenai komoditi atau barang yang dijadikan objek transaksi jual beli online tergantung pada penawaran pihak penjual dan pemesanan dari pembeli, mengenai jenis barang apa dan bagaimana yang akan dibeli.

Dalam transaksi jual beli online, komoditi yang diperdagangkan dapat berupa komoditi digital dan non digital . Komoditi digital seperti surat kabar elektronik, majalah online, digital library, ebook, domain, dan lain-lain, dapat langsungdiserahkan kepada pembeli melalui media internet.

20 Wahbah al-Zuhaili, Al -Figh al -Islami wa Adillatuhu, Jilid IV, 108-109.

${ }^{21}$ Suhartono, Transaksi E-Commerce Syariah (Suatu Kajian terhadap Perniagaan Online dalam Perspektif Hukum Perikatan Islam), 145. 
Sedangkan komoditi non digital ,tidak dapat diserahkan langsung melalui media internet, namun dikirim melalui jasa kurir sesuai dengan kesepakatan spesifikasi komoditi atau barang dan tempatpenyerahan.

Dari keterangan di atas, dapat disimpulkan bahwa belum adanya komoditi pada saat akad, bukanberarti akadnya tidak sah ataupun dikategorikan gharar, karena objek dalam transaksijual beli online, meski belum ada pada saat akad, tetap dipastikan ada kemudian hari.

Pembeli tidak dapat melihat langsung objek dalam transaksi jual beli online, karena yang ditampilkan di internet adalah berupa foto benda tersebut, sehingga pembelisulit memastikan apakah barang itu ada atau tidak. Tetapi, barang yang ditransaksikan dalam jual beli online ini sebenarnya telah ada dan siap dikirim atau bersifat pemesanan. ${ }^{22}$

Pada dasarnya, objek yang dijadikan komoditi dalam transaksi jual beli online,tidak berbeda dengan transaksi yang ada dalam hukum perikatan Islam, selama objektransaksi tersebut halal, bermanfaat, dan memiliki kejelasan baik bentuk, fungsi dan keadaannya serta dapat diserahterimakan pada waktu dan tempat yang telah disepakati oleh penjual dan pembeli maka transaksi yang dilakukan adalah sah.

\section{Terdapat Nilai Tukar}

Para ulama telah sepakat bahwa nilai tukar pengganti barang dalam transaksi harus dapat ditentukan dan diketahui oleh pihak-pihak yang terlibat dalam transaksi. Hal ini dimaksudkan untuk menghilangkan ketidakjelasan yang dapat menimbulkan perselisihan dikemudian hari, misalnya pembayaran dilakukan dengan uang, harus

\footnotetext{
22 Misbahuddin, E-Commerce dan Hukum Islam, 264.
}

dijelaskan jumlah dan mata uang yang digunakan atau apabila dengan barang, maka harus dijelaskan jenis, kualitas, sifat barang tersebut. ${ }^{23}$

Dalam transaksi jual beli online, sebelum proses pembayaran dilakukan,masing-masing pihak penjual dan pembeli telah menyepakati mengenai jumlah danjenis mata uang yang digunakan sebagai pembayaran serta metode pembayaran yang digunakan. Pada saat penjual dan pembeli telahmencapai kesepakatan, kemudian melakukan pembayaran melalui bank, dan setelah pembayaran telah diterima oleh penjual dan pembeli telah mengirimkan buktipembayaran atau kuitansi pembelian, maka penjual mengirim barang sesuai dengankesepakatan mengenai saat penyerahan dan spesifikasi barang kepada pembeli.

Pembayaran harga dalam transaksi jual beli online pada prinsipnya telahmemenuhi ketentuanketentuan yang ada dalam sistem perikatan Islam. Pembayaran atau harga dalam transaksi jual beli online merupakan sesuatu yang bernilai dan bermanfaat. Uang yang digunakan sebagai alat pembayaran pengganti barang dapat ditentukan dan diketahui oleh pihak-pihak yang terlibat dalam transaksi dandibayarkan sesuai kesepakatan penjual dan pembeli.

Setelah mengkaji rukun dan syarat jual belidalam hukum Islam, maka dapat ditarik kesimpulan bahwa transaksi jual beli onlineini tidak bertentangan dengan hukum Islam, baik dari segi orang yang berakad, sighat(lafal ijab dan kabul), objek transaksi, dan nilai tukar barang, selama dalam transaksi itu tidak ada unsur haram, seperti riba, gharar (penipuan),

\footnotetext{
${ }^{23}$ Suhartono, Transaksi E-Commerce S yariah (Suatu Kajian terhadap Perniagaan Online dalam Perspektif Hukum Perikatan Islam), 146
} 
bahaya, ketidakjelasan,dan merugikan hak orang lain, pemaksaan, dan tentunya barang atau jasa yang jadiobjek transaksi adalah halal, bukan yang bertentangan dengan al-Qur'an dan Hadits.

Jual beli online, jika dilihat dari aspek maqashid syariah, terdapat kemaslahatan, berupa kemudahan transaksi, dan efisiensi waktu. Karena secara syari'at Islam ditetapkan untuk kemaslahatan manusia baik didunia maupundiakhirat. Jual beli dalam hukum Islam juga tidak melihat dari segi jenis atau modelsarana yang digunakan, tetapi lebih ditekankan pada prinsip moral seperti kejujuran dan prinsip kerelaan antara kedua belah pihak.

\section{KESESUAIAN TRANSAKSI}

JUAL BELI ON LINE AKAD SALAM DENGAN FATWA DSN MUI NO 05/DSN-MUI/IV/2000 TENTANG JUAL BELI SALAM

Berdasarkan isi keputusan Fatwa DSN MUI diatas maka tentang transaksi jual beli on line akad salam dapat disimpulkan bahwa sesuai dengan Fatwa DSN MUI No 05/DSNMUI/IV/2000 tentang Jual Beli Salam. Berikut penjelasan secara terperinci tentang transaksi online akad salam.

\begin{tabular}{|c|c|c|}
\hline No & Kriteria & On Line \\
\hline \multirow{3}{*}{1} & \multirow{3}{*}{ Pembayaran } & $\begin{array}{lr}\text { Pembayaran } & \text { secara } \\
\text { tunai melalui kartu } \\
\text { kredit atau transfer } \\
\text { berdasakan jumlah yang } \\
\text { disepakati }\end{array}$ \\
\hline & & $\begin{array}{lr}\text { Pembayaran dilakukan } \\
\text { setelah } & \text { kontrak } \\
\text { kesepakatan (transaksi) }\end{array}$ \\
\hline & & $\begin{array}{l}\text { Pembayaran } \\
\text { (langsung) tidak ada } \\
\text { indikasi } \\
\text { hutang }\end{array}$ \\
\hline
\end{tabular}

\begin{tabular}{|c|c|c|c|}
\hline \multirow{5}{*}{2} & \multirow{5}{*}{ Barang } & $\begin{array}{l}\text { Ciri-ciri barang atau } \\
\text { spesifikasi barang } \\
\text { disampaikan dijelaskan } \\
\text { dalam produk }\end{array}$ & $\begin{array}{l}\begin{array}{l}\text { Harus jela } \\
\text { diakui seba }\end{array} \\
\text { Harus } \\
\text { spesifikasir }\end{array}$ \\
\hline & & \multirow{2}{*}{$\begin{array}{l}\text { Penyerahan barang } \\
\text { dilakukan kemudian } \\
\text { hari setelah masa } \\
\text { pembayaran dan sesuai } \\
\text { dengan kesepakatan } \\
\text { 9konsumen memilih } \\
\text { jasa pengiriman) }\end{array}$} & $\begin{array}{l}\text { Penyerahan } \\
\text { kemudian. }\end{array}$ \\
\hline & & & $\begin{array}{l}\text { Waktu da } \\
\text { barang har } \\
\text { berdasarkar }\end{array}$ \\
\hline & & \multirow[t]{2}{*}{$\begin{array}{l}\text { Menjadi hak penuh } \\
\text { pembeli awal }\end{array}$} & $\begin{array}{l}\text { Pembeli } \\
\text { barang seb }\end{array}$ \\
\hline & & & $\begin{array}{l}\text { Tidak bol } \\
\text { kecuali der } \\
\text { sesuai kese }\end{array}$ \\
\hline & & & \\
\hline
\end{tabular}

Oleh karenanya jual beli online sesuai dengan Fatwa DSN, maka diharapkan kepada pelaku usaha maupun konsumen tidak ada melanggar suatu kegiatan perekonomian tersebut yang dapat merugikan masing-masing pihak. Dan kegiatan ekonomi tersebut harus terus digalakkan untuk menunjang perekonomian rakyat yang berbasis syariah.

Dikâtakă DŞekali lagi bahwa transaksijual beli online mempunyai banyak kemudahan bagi baipenjual maupun dan pembeli. Penjual paik hanya bermodalkan memasarkan produk lewat umedißBaranline atain hanya melihat produk yang dipasarkan

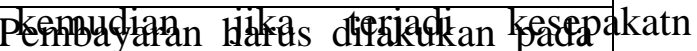
sterikdilahakadksepreiły jual beli dengan sistem akad salam.

PKFISAYAdPbLA boleh dalam bentuk pEnalkeblasjarahbedingn line melalui instagram@ppshope88 adalah mudah karena pemesanan melalui internet atau instagram sangat mudah dan cepat, 
tidak terhalang oleh waktu dan tempat, diwaktu kapanpun dan ditempat manapun. Dengan mengakses internet dan membuka instagram @ppshope88 tersebut kita selaku konsumen bisa langsung memesan barang yang kita inginkan berdasarkan kriteria tertentu dan dilanjutkan kesepakatan antara pihak tentang terjadinya akad tersebut.

Keabsahan tentang jual beli on line melalui instagram @ppshope88 akan tetap absah/sah karena sudah sesuai dengan kaidah-kaidah syariat islam yang mengatur tentang jual beli, ia tidak mengandung unsur ketidakjelasan maupun penipuan.

Transaksi jual beli online akad salam sesuai dengan Fatwa DSN MUI No 05/DSN-MUI/IV/2000 tentang Jual Beli Salam, dikarenakan dalam akad tersebut tidak menyalahi aturan syariat yang ada, sehingga kedepannya adanya Fatwa tersebut harus diakui keberadaannya dan diimplementasikan dalam kegiatan ekonomi yang dimaksud. 


\section{DAFTAR PUSTAKA}

Buchari Alma, Dasar-Dasar Etika Bisnis Islam (Bandung: Alfabeta, 2003)

Supriyadi, Hukum Bisnis (Bandung: PT Rineka, 2008)

Agoeng Noegroho, Teknologi Komunikasi (Yogyakarta: Graha Ilmu, 2010)

www.articles of business system.com, diakses tanggal 02 Agustus 2017

www. Okezone. com. Diakses pada tanggal 02 Agustus 2017

http://www.selipan.com/story/style/7alasan-kenapa-pendudukinstagramkebanyakan-cewek/, diakses pada 27 Februari 2018

Mariam Darus Badrulzaman, ECommerce Tinjauan Dari Hukum Kontrak Indonesia, (Jakarta: Citra Aditya Bakti, 2001)

Abdul Halim Barakatullah dan Teguh Prasetyo, Bisnis E-Commerce Studi Sistem Keamanan dan Hukum di Indonesia (Jakarta: Pustaka 2008)

Sril Sitompul, Hukum Internet, (Bandung: Citra Aditya Bakti, 2004)

Setiawan, Electronic Commerce: Tinjauan Dari Segi Hukum Kontrak, (Jakarta: Rineka Cipta, 2000)

Neni Sri Imaniyati, Hukum Bisnis, (Yogjakarta: Graha Ilmu, 2013)

Ana Faiqoh Jurusan. 2011. Penjiblakan Karya Tulis di Internet Dalam Pandangan Hukum Islam.

Sayid Hamid. 2011. Penggunaan Merek Orang Lain Sebagai Domain Name Internet Dalam Perspektif Undang-Undang Merek dan Hukum Islam

Abdulkadir Muhammad, Hukum dan Penelitian Hukum, (Bandung: PT Citra Abadi, 2004)
Cik Hasan Bisri, Pilar-pilar Penelitian Hukum Islam dan Pranata Sosial

Husin Sayuti, Pengantar Metode Rised, ( Jakarta: Fajar agung, 1989 )

Djaman Satori, Metodologi Penelitian Kualitatif, (Bandung: Alfabeta, 2010)

Amir Syarifuddin, Garis-Garis Besar Fiqh, (Jakarta: Prenada Grup, 2007)

Hendi Suhendi, Fiqh Mu'amalah, (Jakarta: PT Raja Grafindo Persada, 2010)

Wahbah al-Zuhaili, Al -Fiqh al -Islami wa Adillatuhu, Jilid IV (Beirut: Dar al-Fikr, 1989)

Sofyan AP. Kau, Tinjauan Hukum Islam Tentang Jual Beli Via Telepon dan Internet,

Wahbah al-Zuhaili, Al-Fiqh al -Islami wa Adillatuhu, Jilid IV, 108-109

Suhartono, Transaksi E -Commerce Syariah (Suatu Kajian terhadap Perniagaan Online dalam Perspektif Hukum Perikatan Islam), 145.

Misbahuddin, E-Commerce dan Hukum Islam, 264.

Suhartono, Transaksi E-Commerce S yariah (Suatu Kajian terhadap Perniagaan Online dalam Perspektif Hukum Perikatan Islam) 